\title{
Emotional intelligence, empathy, extraversion, alexithymia, environmentally responsible behavior in students-carriers of different MAOA, COMT gene genotypes
}

\author{
Elena Vorobyeva ${ }^{1,2}$, Ekaterina Kovsh $^{2}$, Ekaterina Denisova ${ }^{1}$, Daria Alekseeva ${ }^{2}$, and Vitaly \\ Babenko ${ }^{1,2, *}$ \\ ${ }^{1}$ Don State Technical University, 344003, Rostov-on-Don, Gagarin Square, 1, Russia \\ ${ }^{2}$ Southern Federal University, 344006, Rostov-on-Don, st. Bolshaya Sadovaya, 105/42, Russia
}

\begin{abstract}
The article is devoted to the study of the association of genotypes of genes of monoamine oxidase A (MAOA) and catechol-Omethyltransferase (COMT) with emotional intelligence and personality traits of young people, such as extraversion-introversion, empathy, and alexithymia. The work was attended by students-psychologists, in the amount of 100 people. The following methods were used: Test of emotional intelligence (D.V. Lyusin); Emotional Empathy Questionnaire (A. Mehrabian, N. Epstein); «Big five» test; Toronto Alexithymia Scale. For statistical processing of the results obtained, we used multivariate analysis of variance ANOVA with Tukey's post hoc analysis for non-equilibrium sample sizes. As a result, it was found that the genes of the monoaminergic system COMT and MAOA are associated with the general level of emotional intelligence. Women, in general, showed a lower level of emotional intelligence. The Met/Met genotype of the COMT gene is associated with a higher level of emotional intelligence and high extraversion. The Val/Met genotype of the COMT gene in women is associated with low emotional intelligence and low empathy. The Val/Val genotype of the COMT gene in men is associated with extraversion. In the work, no associations were found between the genotypes of the MAOA, COMT genes, and the level of alexithymia.
\end{abstract}

\section{Introduction}

Emotional intelligence, as the ability to understand other people's emotions and to express one's own emotions and to manage emotions, as well as the ability to show empathy, are important components of mental health. For example, unwillingness or inability to express one's own emotions, as well as the negative emotional environment in the family, are important environmental risk factors for the occurrence of such endogenous mental disorders as depressive spectrum disorders [1]. Empathy is manifested as the ability to sympathy and is an important human trait that provides its owner with effective communication and

\footnotetext{
*Corresponding author: evorob2012@yandex.ru
} 
adaptation in society. Empathy is closely related to emotional intelligence and affects the ability to recognize emotional facial expressions [2]. Empathy can be reduced in mental illness, such as schizophrenia [3].

Genetic studies of the association of various genes with personality traits, including those describing the emotional-volitional sphere, are mainly focused on the study of genes of neurotransmitter systems and enzymes of their metabolism [4]. The enzyme monoamine oxidase A (MAOA) promotes the breakdown of dopamine and serotonin in the intersynaptic space, and catechol-O-methyltransferase (COMT) is involved in the transmission of catecholamines (dopamine, norepinephrine, adrenaline).

The monoamine oxidase A (MAOA) gene is behaviorally associated with impulsivity and aggression [5]. The number of tandem repeats (VNTR) in the promoter region of this gene determines the activity of this allele. In the case of a larger number of repeats (long allele MAO A), the MAOA enzyme promotes faster breakdown of dopamine and serotonin. The short MAOA allele is less active, as a result of which neurotransmitters remain in the intersynaptic space longer, and at the behavioral level, this manifests itself as a more pronounced aggressiveness of carriers. It has been shown that female carriers of the allele with three repeats (lower expression of MAOA) demonstrate a higher level of emotional stability and impulse control [6]. At the same time, women with a highly active variant of MAOA, who were abused in childhood, demonstrated a higher level of emotional reactivity $[7 ; 8]$.

The catechol-O-methyltransferase (COMT) gene is located on chromosome 22q11 and contains the Val158Met polymorphic locus $(472 \mathrm{~A}>\mathrm{G}$, rs4680). There are three variants of the COMT gene genotype: GG homozygotes - (Val / Val) - have a high activity of the COMT enzyme and an average level of dopamine in the intersynaptic space; heterozygotes GA (Val / Met) - have intermediate activity of the COMT enzyme and dopamine levels above average; AA homozygotes - (Met / Met) - have a low activity of the COMT enzyme and a high concentration of dopamine in the intersynaptic space. Since the Met allele encodes a less efficient variant of the COMT enzyme, resulting in higher levels of extra-synaptic prefrontal dopamine, these observations further support a role for dopamine in intelligence and extraversion [9]. Emotional intelligence is associated with the COMT gene, while different genotypes of the COMT gene are associated with the process of categorizing emotionally charged and neutral visual scenes, and this relationship is reflected in the parameters of evoked potentials [10]. During the student period, youth becomes a frequent object of psychological research, since it is during the period of education that the main professionally important qualities and motivation are formed $[11 ; 12 ; 13 ; 14]$. Such personal qualities of young people as extraversion-introversion, empathy, emotional intelligence, alexithymia also become the subject of study. Education at the university is associated with mental overloads, often associated with a period of material instability, can cause anxiety, and be accompanied by the student's inability to verbally express their emotions and feelings, that is, alexithymia $[15 ; 16]$.

This work aims to study the association of the genotypes of the MAOA and COMT genes with emotional intelligence and personality traits of young people, such as extraversionintroversion, empathy, emotional intelligence and alexithymia.

\section{Materials and methods}

The sample consisted of 100 psychology students studying at the universities of Rostov-onDon (68\% - girls), average age - 19.3 years, it was right-handed people without pronounced health problems. In our work, we carried out genotyping of study participants for the MAOA and COMT genes. 
Based on the laboratory «Biological Solutions and Technologies» (Russia, Moscow), DNA analysis, PCR for the polymorphic Val158Met locus of the COMT gene and agarose gel electrophoresis for uVNTR of the MAOA gene were carried out. Distribution of genotype frequencies. MAOA gene: highly active genotypes $\mathrm{H}$ (4 repeats of the promoter region of the gene) - 22\%; low-activity genotypes L ( 5 repeats of the promoter region of the gene) - $50 \%$; heterozygous genotypes M (5/4 repeats of the promoter region of the gene) - $28 \%$. COMT gene: highly active $\mathrm{Val} / \mathrm{Val}$ genotypes - 16\%; low-activity genotypes Met/Met - 29\%; heterozygous Val/Met genotypes - 55\%.

The paper hypothesized that the genotypes for the MAOA and COMT genes can be associated with the level of emotional intelligence and personality traits of young people, such as empathy, extraversion-introversion, and alexithymia.

Research methods. Test (self-report questionnaire) of emotional intelligence (D.V. Lyusin) [17]. EETS Emotional Empathy Questionnaire by A. Mehrabian, N. Epstein as adapted by Y.M. Orlov, Yu.N. Emelyanov [18]. «Big five» personality test 5PFQ, adapted by A.B. Khromov [19]. Toronto Alexithymia Scale, TAS-26 by G. Taylor et al. in adaptation by D.B. Eresko, G.L. Isurina and others [20].

For statistical processing of the results obtained, multivariate analysis of variance ANOVA (Statistica 13.0; factors «COMT gene», «MAOA gene», «gender») was applied with Tukey's post hoc analysis for non-equilibrium sample sizes.

\section{Results}

\subsection{Emotional intelligence}

According to the results of this study, no significant influence of the COMT gene and the combination of the COMT gene * sex factors on the general level of emotional intelligence was revealed $(\mathrm{F}=2.4, \mathrm{MS}=195.2, \mathrm{SS}=390.5, \mathrm{p}=0.1)$, however, according to the results of Tukey's post-hoc analysis, it was shown that carriers of the Met/Met genotype of the COMT gene have a significantly higher general level of emotional intelligence $(M=90.6, p$ $=0.04$; in particular, men, $\mathrm{M}=93.8, \mathrm{p}=0.05)$. Carriers of the Val/Met genotype of the COMT gene have the lowest level of general emotional intelligence in the studied sample $(\mathrm{M}$ $=85.5, \mathrm{p}=0.04$; in particular, women, $\mathrm{M}=85.3, \mathrm{p}=0.05)$ (Fig. 1).

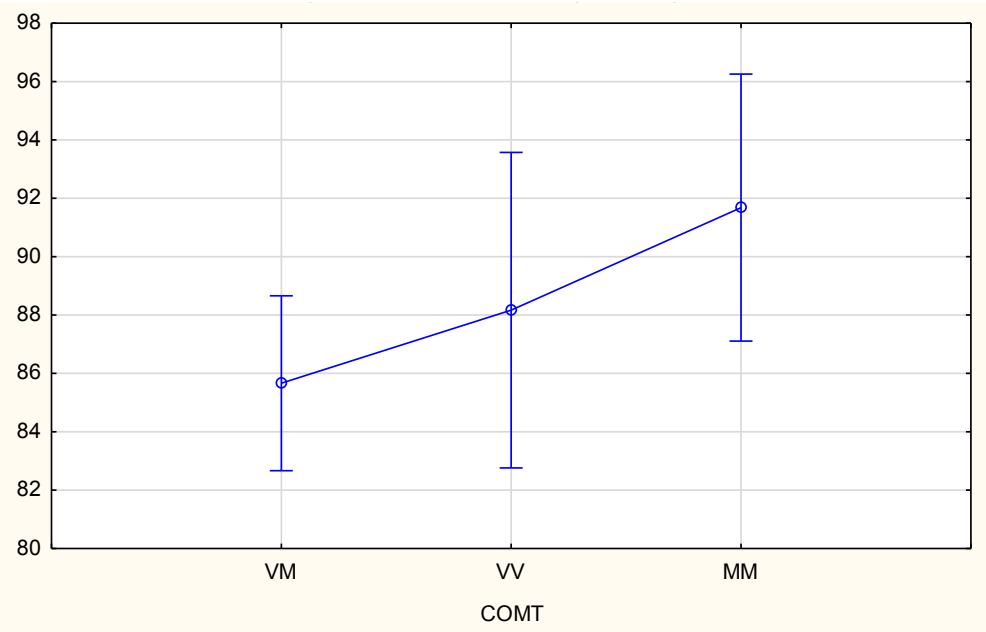


Fig. 1. Results of analysis of variance of the level of emotional intelligence (along the vertical axis) in carriers of different genotypes of the COMT gene (ANOVA, $p \leq 0.05$ ).

Designations: VM - heterozygous genotype of the COMT gene; VV - highly active homozygous genotype of the COMT gene; MM - low active homozygous genotype of the COMT gene.

A significant influence of the combination of factors «MAOA gene * sex» on the general level of emotional intelligence was revealed $(\mathrm{F}=5.5, \mathrm{MS}=422.7, \mathrm{SS}=422.7, \mathrm{p}=0.02)$. In general, carriers of the heterozygous genotype (women) have lower indicators of emotional intelligence $(\mathrm{M}(\mathrm{M})=84.7, \mathrm{p}=0.05)$, compared with carriers of high- and low-active genotypes $(\mathrm{M}(\mathrm{H})=88.3, \mathrm{Ml}=88.2, \mathrm{p}=0.05)$. In the group of men, carriers of the highly active genotype $\mathrm{H}$ have higher indicators of emotional intelligence compared to carriers of the low-active genotype $\mathrm{L}(\mathrm{M}(\mathrm{H})=91.4, \mathrm{M}(\mathrm{L})=84.7, \mathrm{p}=0.05)$. In the group of women, carriers of the low-active genotype $\mathrm{L}(\mathrm{M}(\mathrm{L})=90.1, \mathrm{p}=0.05)$ have the highest indicator of emotional intelligence (Fig. 2).

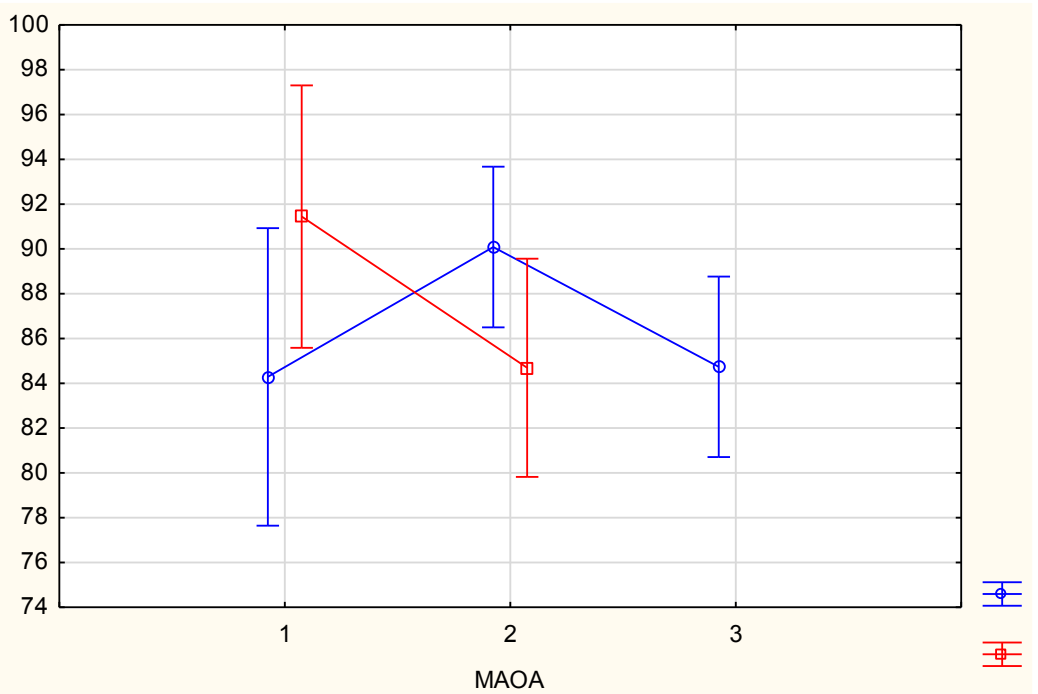

Fig. 2. Results of analysis of variance of the level of emotional intelligence (along the vertical axis) in carriers of different genotypes of the MAOA gene, men (red line) and women (blue line) (ANOVA, $\mathrm{p} \leq 0.05)$.

Designations: 1 - highly active genotype of the MAOA gene, $\mathrm{H} ; 2$ - low-activity genotype of the MAOA gene, L; 3 - heterozygous genotype of the MAOA gene, M.

\subsection{Extraversion-introversion}

The combination of factors "COMT gene * sex" has a significant effect on the extraversionintroversion index $(\mathrm{F}=4.0, \mathrm{MS}=392.6, \mathrm{SS}=785.3, \mathrm{p}=0.02)$. According to the results obtained, in men the $\mathrm{Val} / \mathrm{Val}$ genotype of the COMT gene is associated with introversion $(\mathrm{M}(\mathrm{Val} / \mathrm{Val})=40.0, \mathrm{p}=0.03)$, the Met/Met genotype - with extraversion $(\mathrm{M}(\mathrm{Met} / \mathrm{Met})=$ 59.4, $\mathrm{p}=0,03$ ) (Fig. 3).

Designations: blue line - VM, heterozygous genotype of the COMT gene; red line - VV, highly active homozygous genotype of the COMT gene; green line - MM, low active homozygous genotype of the COMT gene. 
The factor «MAOA gene», as well as the combination of factors «MAOA gene * sex» do not have a significant effect on the indicator of extraversion-introversion $(\mathrm{F}=0.2, \mathrm{MS}=25.9$, $\mathrm{SS}=25.9, \mathrm{p}=0.6$ ).

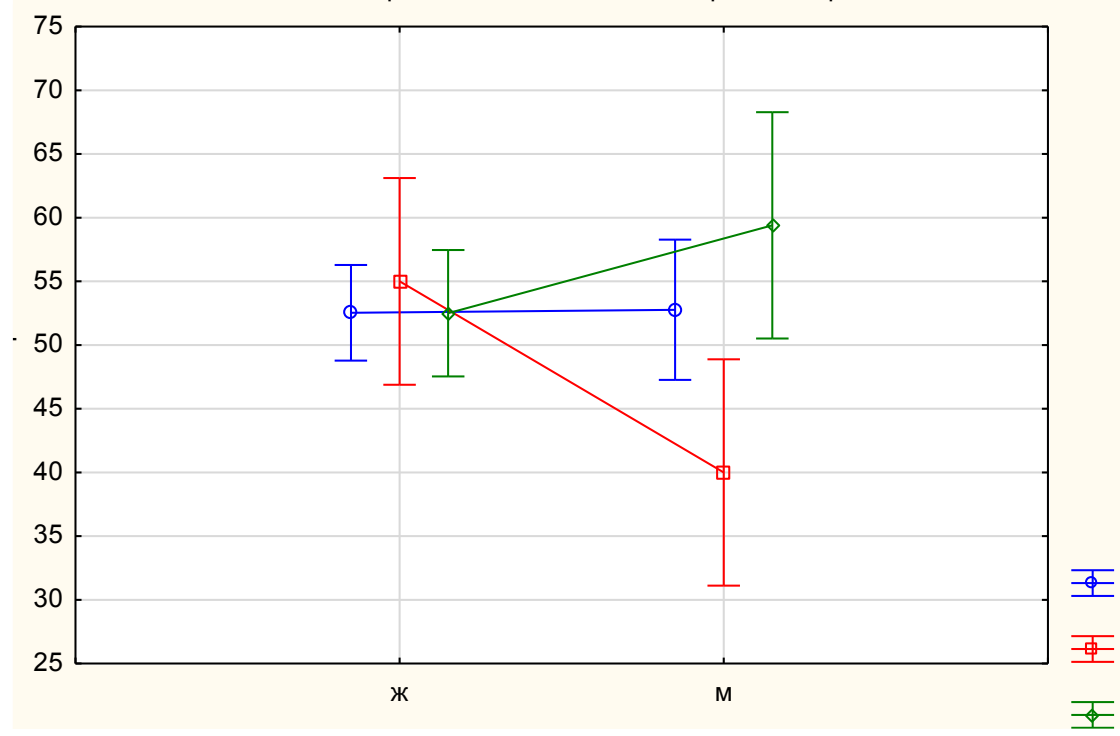

Fig. 3. Results of analysis of variance of extraversion-introversion (along the vertical axis) in carriers of different genotypes of the COMT gene, men (m) and women (ж) (ANOVA, $\mathrm{p} \leq 0.05$ ).

\subsection{Empathy}

No significant influence of the combination of factors «COMT gene * sex» on the level of empathy was revealed $(\mathrm{F}=0.6, \mathrm{MS}=12.6, \mathrm{SS}=25.2, \mathrm{p}=0.5)$, however, in the course of a posteriori analysis it was found that men who are carriers of the Val/Met genotype of the COMT gene $(\mathrm{M}(\mathrm{Val} / \mathrm{Met})=20.0, \mathrm{p}=0.003)$ have a significantly lower level of empathy in the study sample; women have a higher level of empathy in general (Fig. 4). 


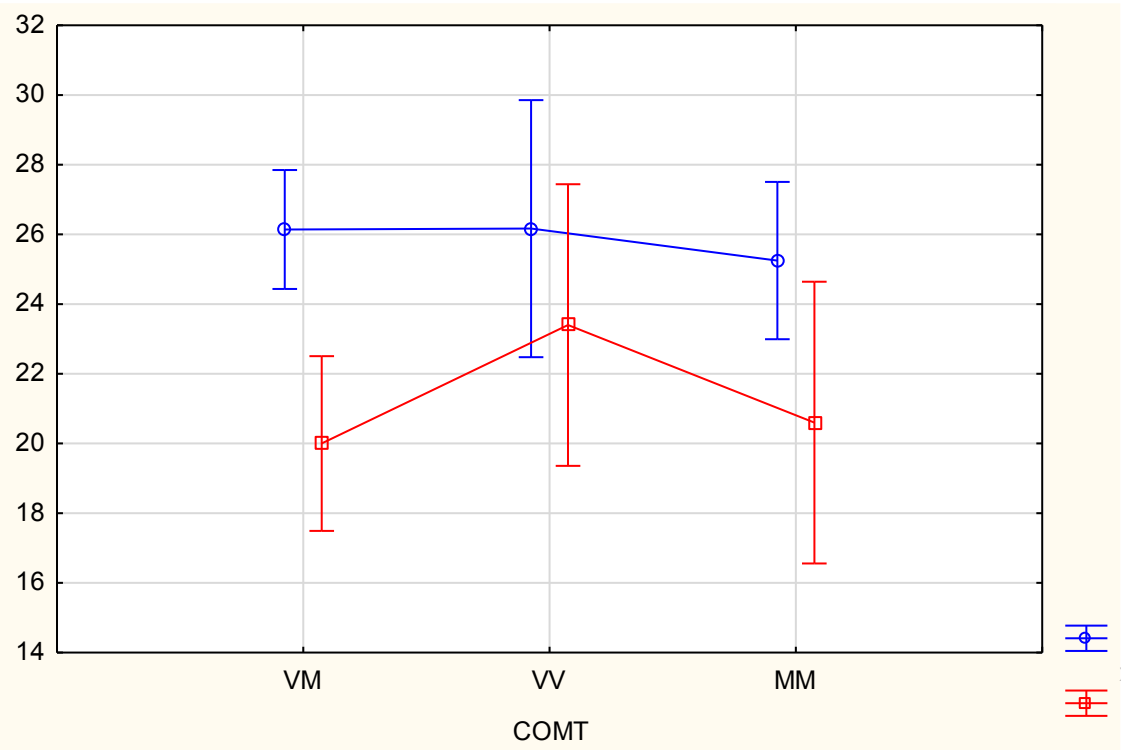

Fig. 4. Results of analysis of variance of the level of empathy (along the vertical axis) in carriers of different genotypes of the COMT gene, men (red line) and women (blue line) (ANOVA, $p \leq 0.05$ ).

A significant influence of the combination of factors «MAOA gene * sex» on the level of empathy was revealed $(\mathrm{F}=8.7, \mathrm{MS}=158.9, \mathrm{SS}=158.9, \mathrm{p}=0.005)$. Men who are carriers of the highly active genotype of the MAOA gene have a significantly lower level of empathy in the study sample $(\mathrm{M}(\mathrm{H})=17.9, \mathrm{p}=0.000)$.

\subsection{Alexithymia}

There was no significant influence of the factors «COMT gene», «MAOA gene» on the level of alexithymia $(\mathrm{p}>0.05)$.

\section{Discussion}

\subsection{Emotional intelligence}

According to the data obtained in our work, the carriers of the Met/Met genotype of the COMT gene, especially men, have a higher level of emotional intelligence, diagnosed using the self-report questionnaire of D.V. Lyusin. Carriers of the Val/Met genotype of the COMT gene, especially women, have the lowest level of emotional intelligence. Different approaches to understanding emotional intelligence include considering it as a personality trait or, in contrast, as an ability. In this work, we used D.V. Lyusin's self-report questionnaire to diagnose emotional intelligence, which is based on the first approach. According to the theory of J. Meyer, P. Salovey and D. Caruso (the second approach), emotional intelligence is understood as the ability to perceive emotions, understand emotions and control their emotions and the emotions of other people to solve practical problems [21].

Carriers of the heterozygous genotype of the MAOA gene (women) have lower indicators of emotional intelligence compared to carriers of high- and low-active genotypes. In the group of women, the carriers of the low-active genotype L have the highest indicator of emotional intelligence. In the group of men, carriers of the highly active genotype $\mathrm{H}$ have 
higher indicators of emotional intelligence, compared with carriers of the low-active genotype L.

\subsection{Extraversion-introversion}

In our work, it was found that the COMT genotype is associated with the severity of extraversion-introversion in men, while the $\mathrm{Val} / \mathrm{Val}$ genotype of the COMT gene is associated with introversion, and the Met/Met genotype is associated with extraversion. In previous works by other authors, also on a sample of healthy men, it was shown that carriers of the Met allele have a lower extraversion score [9]. However, later, in 2016, in a metaanalysis of genome-wide studies of 63030 participants from 29 cohorts, it was concluded that the additive variance explained by SNP polymorphisms did not differ significantly from zero, and extraversion is a polygenic personality trait [22].

As for the MAOA gene, our work did not reveal any associations of the genotype for this gene with extraversion-introversion. At the same time, there are indications in the literature on the association of genetically variations of the MAOA gene measured by three SNPs (rs3788862, rs5906957, and rs979606) with extraversion, estimated in the longitude from 16 to 26 years old [23].

\subsection{Empathy}

We found that men who are carriers of the Val/Met genotype of the COMT gene have a significantly lower level of empathy, while women have a higher level of empathy in general. Men who are carriers of the highly active genotype of the MAOA gene have a significantly lower level of empathy. In our previous works, it was found that there are statistically significant differences in the severity of personality traits in female carriers of diplotypes at the Val158Met COMT and -uVNTR MAOA polymorphic loci [24]. As part of the comparison of our data with the data of other authors, we note that currently the data on the possible association of the COMT gene and empathy, obtained on samples of people with psychopathology, are contradictory. Thus, on a sample of patients with schizophrenia, the relationship between the ability for interpersonal empathy and the rs4680 COMT polymorphism was shown [25]. For adolescents aged 10-17 years with a diagnosis of ADHD, no associations of fear empathy and genotype for the COMT Val158Met gene were obtained [26]. On a sample of healthy people in one of the latest studies, no data were obtained on the association of empathy, measured on the Davis Interpersonal Reactivity Index scale, and the COMT rs4680 gene [27]. It was also found that a low-activity variant of the MAOA gene (MAOA-L) is associated with an increased risk of aggressive behavior in its carriers [28]. In a study of empathy in men and women, conducted on a large sample of more than 10000 people, it was found that there is a slight advantage in the expression of empathy in women, while women rate their empathy higher in self-report questionnaires [29].

\subsection{Alexithymia}

In previous works, as in ours, no data were obtained on significant associations of the Val158Met COMT polymorphism and alexithymia [30; 31].

\section{Conclusions}

Based on the results obtained, it can be concluded that genes of the monoaminergic system COMT and MAOA are associated with the general level of emotional intelligence, which 
affect the activity of enzymes that break down monoamines. At the same time, unequal results were obtained for men and women: women in general showed a lower level of emotional intelligence, according to a self-report questionnaire.

The Met/Met genotype of the COMT gene is associated with a higher level of emotional intelligence and high extraversion (especially in men), which may be associated with a longer and more effective thinking about tasks aimed at determining the level of emotional intelligence (the low-activity genotype of the COMT gene is associated with prolonged activation of the prefrontal cortex). The Val/Met genotype in women is associated with low emotional intelligence and low empathy. The Val/Val genotype in men is associated with introversion.

For the MAOA gene, the following results were obtained: in men, the low-activity genotype is associated with a higher general level of emotional intelligence, while in women it (as well as the heterozygous genotype) is associated with a lower severity of this characteristic. These results are consistent with the unequal data on the relationship between the low-activity genotype of the MAOA gene and the level of aggressiveness: in most studies, this relationship, under the influence of unfavorable environmental factors (violence in childhood), is shown in men, but not in women.

The following combination is noteworthy: the presence of high emotional intelligence and a low level of empathy in men with a highly active genotype of the MAOA gene. This combination may indicate that this group of men may have developed components of emotional intelligence that are not directly related to empathy, for example, emotion control. In our study, no associations were found between the genotypes of the MAOA and COMT genes and the level of alexithymia.

\section{Acknowledgements}

This work has been supported by the grants of the Russian Science Foundation, RSF 20-6447057.

\section{References}

1. Meng, X., Kou, C., Shi, J., et al.: Journal of Affective Disorders. 1-2(132), 254-259 (2011) DOI: 10.1016/j.jad.2011.01.005

2. Kosonogov, V., Titova, A., Vorobyeva, E.: Quarterly Journal of Experimental Psychology 68 (10), 2106-2115 (2015) DOI:10.1080/17470218.2015.1009476

3. Liu, Y., Li, J.-Y.: Journal of Jilin University Medicine Edition 40(6), 1266-1269 (2014).

4. Kosonogov, V.V., Vorobyeva, E.V., Kovsh ,E.M., Ermakov, P.N.: International Journal of Cognitive Research in Science, Engineering and Education 7(1), 137-142 (2019). DOI: $10.5937 /$ ijcrsee1901137K

5. Rodríguez-Ramos, Á., Moriana, J.A., García-Torres, F., Ruiz-Rubio, M.: Brain Behav. 9:e01376 (2019).

6. Nilsson, K.W., Åslund, C., Comasco, E. et al.: J. Neural. Transm. 125, 1601-1626 (2018). https://doi.org/10.1007/s00702-018-1892-2

7. Nikolaeva, E.: Psychology and Health.19 (SUPPL. 1), 121 (2004).

8. Byrd, A. L., Manuck, S. B., Hawes, S. W., et al., Development and Psychopathology, 31(1), 361-377 (2019).

9. Wacker, J., Mueller, E. M., Hennig, J., \& Stemmler, G.: Journal of Personality and Social Psychology 102(2), 427-444 (2012) https://doi.org/10.1037/a0026544 
10. Vorobyeva, E.V., Ermakov, P.N., Borokhovski, E.F. et al.: Association between categorization of emotionally-charged and neutral visual scenes and parameters of eventrelated potentials in carriers of different COMT, HTR2A, BDNF gene genotypes. F1000Research, 9:446 https://doi.org/10.12688/f1000research.22503.2

(2020)

11. Vorobyeva, E.V., Ermakov, P.N., Saakyan, O.S.: Psychology in Russia: State of the Art. 8(1), 32-42 (2015) DOI: 10.11621/pir.2015.0104

12. Romano, L., Buonomo, I., Callea, A., Fiorilli, C.: Journal of Genetic Psychology. 180 (4-5), 157-169 (2019) DOI: 10.1080/00221325.2019.1620675

13. Franzoi, I.G., Sauta, M.D., Granieri, A.: Frontiers in Psychology 11, 1255 (2020) DOI:10.3389/fpsyg.2020.01255

14. Efremova, N., Huseynova, A.: E3S Web of Conferences 175, 15015 (2020) INTERAGROMASH (2020) https://doi.org/10.1051/e3sconf/202017515015

15. Kozhukhar, G., Belousova, A., Breus, E.: E3S Web Conf. Innovative Technologies in Science and Education (ITSE-2020) 210 (2020) DOI: https://doi.org/10.1051/e3sconf/202021018009

16. Azarko, E., Abakumova, I., Kupriyanov, I.: E3S Web of Conferences 210 (2020) DOI: $10.1051 / \mathrm{e} 3 \operatorname{sconf} / 202021018004$

17. Lyusin, D.V.: Psihologicheskaya diagnostika 4, 3 - 22 (2006).

18. Psihodiagnostika tolerantnosti lichnosti M.: Smysl, (2008).

19. Hromov, A.B.: Pyatifaktornyj oprosnik lichnosti. Kurgan: KGU (2000).

20. Eres'ko, D.B., Isurina, G.L., Kajdanovskaya, E.V., et al., Aleksitimiya i metody eyo opredeleniya pri pogranichnyh psihosomaticheskih rasstrojstvah. SPb.: NIPNI im. Bekhtereva (2005).

21. Caruso, D.R., Salovey, P.: The Emotionally Intelligent Manager: How to Develop and Use the Four Key Emotional Skills of Leadership. San Francisco: Josses-Bass, (2004).

22. van den Berg, S.M., de Moor, M.H.M., Verweij, C.J.H., et al, Meta-analysis of GenomeWide Association Studies for Extraversion: Findings from the Genetics of Personality Consortium. Behavior Genetics, 46(2), 170-182 (2016) https://doi.org/10.1007/s10519015-9735-5

23. Xu, M.K., Gaysina, D., Tsonaka, R., et al., Frontiers in Psychology, 8, Article 1736 (2017) https://doi.org/10.3389/fpsyg.2017.01736

24. Kovsh, E., Ermakov, P., Vorobyeva, E.: Behavior Genetics 47 (6), 673 (2017) DOI 10.1007/s10519-017-9879-6

25. Poletti, S., Radaelli, D., Cavallaro, R., ettt al., Comprehensive Psychiatry 54 (2), 181186 (2013) DOI: 10.1016/j.comppsych.2012.06.008

26. Van Goozen, S.H.M., Langley, K., Northover, C., et al., Journal of Child Psychology and Psychiatry and Allied Disciplines 7 (4), 472-480 (2016) DOI: 10.1111/jcpp.12464

27. Huetter, F.K., Moehlendick, B., Knop, D., Siffert, W.: Hormones and Behavior 126, 104841 (2020) DOI: 10.1016/j.yhbeh.2020.104841

28. Klasen, M., Wolf, D., Eisner, P.D., et al., Brain Structure and Function 223 (2), 873-881 (2018) DOI: 10.1007/s00429-017-1528-6

29. Baez, S., Flichtentrei, D., Prats, M., Mastandueno, R., Garcia, A.M., Cetkovich, M., Ibanez, A.: PLOS ONE 12(6), e0179336 (2017) DOI: 10.1371/journal.pone.0179336 
30. Hermes, S., Hennig, J., Stingl, M., Leichsenring, F., Leweke, F.: Zeitschrift fur Psychosomatische Medizin und Psychotherapie 57(1), 51-61 (2011) DOI: 10.13109/zptm.2011.57.1.51

31. Zekioglu, A., Cam, F.S., Mutluturk, N., Berdeli, A., Colakoglu, M.: International Journal of Human Genetics 14(1), 43-48 (2014). 